\title{
TOWARDS MORE EFFECTIVE MANAGEMENT OF HIGH SEAS FISHERIES*
}

\author{
Edward L. Miles**
}

\section{INTRODUCTION}

The issue of management of high seas fisheries has increased rapidly in salience over the last five years. Increasing concern by coastal State officials and the general public has been generated by various conflicts which have occurred over stocks which straddle exclusive economic zones (EEZs) and the high seas; by conflicts over the harvest of marine mammals, especially cetaceans, on the high seas; and by conflicts over the use of large-scale pelagic driftnets and the level of incidental or non-target catch (bycatch) associated with the use of this type of fishing gear.

Canada and the South Pacific island States, in particular, working together at the UN Conference on Environment and Development (UNCED) in Rio de Janiero in June 1992, succeeded in getting high priority to be placed on convening an international conference in July 1993 to consider the problems of high seas fisheries management. The concerns of the Canada/South Pacific coalition focused primarily on the problems of straddling stocks for Canada and highly migratory species, particularly tuna and tuna-like species, for South Pacific island States. But the truth is that the record of management for almost all high seas fisheries is quite poor.

\footnotetext{
* 20 July 1993. An earlier version of this paper was delivered as a lecture to the international workshop on "Challenges to Fishery Policy and Diplomacy in Southeast Asia," organized by SEAPOL and held at Rayong, Thailand, 6-10 December 1992.

** Director, School of Marine Affairs, College of Ocean and Fishery Sciences, University of Washington, Seattle.
}

Asian Yearbook of International Law, Volume 3 (Ko Swan Sik et al., eds.; 0-7923-2708-X; (C) 1994 Kluwer Academic Publishers; printed in Great Britain), pp. 111-127 
The only example of successful high seas fisheries management to which one can readily point concerns the harvest of Northern Fur Seals in the Pacific Ocean/Bering Sea. Originally negotiated in 1911 between the US, UK (on behalf of Canada), Russia, and Japan, and reconfirmed in 1957 with Canada replacing the UK, the North Pacific Fur Seal Convention prohibited pelagic sealing and created a Commission to manage the harvest of males only at rookeries. ${ }^{1}$ The 1957 Convention also prohibited pelagic sealing on a commercial basis and allocated the catch on a 70:30 basis, i.e. 70 per cent to the rookery States (USSR and USA) and 30 per cent to Japan and Canada. However, neither Japan nor Canada harvested any seals. The rookery States harvested 100 per cent of the catch and paid 30 per cent of the proceeds of sales to Japan and Canada.

On the basis of more than 300 years' experience with the Grotian, i.e. open access, regime governing the management of marine fisheries, we have learned that this regime carried in its train primarily flag State jurisdiction, a unanimity requirement to implement management decisions within regional commissions, and weak surveillance and enforcement practices beyond the territorial sea. The combined result of these three antecedent conditions is always the tragedy of the commons, as defined by GARRETT HARDIN, ${ }^{2}$ i.e. there is no incentive for any vessel to leave resources in the ocean for tomorrow because, inevitably, what is left will be taken by someone else today. ${ }^{3}$

We can therefore generalise the lessons we have learned from the experience of the Grotian regime in the following way: the key question in the international management of fisheries is always control over the stocks. If the authority to manage is fragmented and participation in the management system is voluntary, with serious constraints on surveillance and enforcement, then biological and economic waste will be high, conflict will be endemic in the system, decision systems will be cumbersome, decision times will be protracted, and management effectiveness will be low.

Largely in response to the perceived ineffectiveness of the Grotian regime, the Third United Nations Conference on the Law of the Sea (UNCLOS III) enshrined within the 1982 UN Convention on the Law of the Sea a system, based on the EEZ concept, which effectively gives to the coastal State property rights in living resources within a zone of 200 miles adjacent to the coast. We

1 Edward Miles et al, The Management of Marine Regions: The North Pacific, Berkeley, Los Angeles, and London, University of California Press, 1982, Chapter 3, esp. pp. 58-61.

2 GARRETT HARDIN, "The Tragedy of the Commons", Science, Vol. 162 (1968), pp. 1243-1248. 3 The conditions that HARDIN characterized as the tragedy of the commons were first elaborated in relation to fisheries by H. ScotT GoRDon, "The Economic Theory of a Common Property Resource: The Fishery", Journal of Political Economy, Vol. 62 (1954), pp. 124-142. Gordon's approach was later elaborated into a classic analysis of the global problem by FRANCIS T. CHRISTY Jr., and ANTHony Scotr, The Common Wealth in Ocean Fisheries, Baltimore and London, The John Hopkins Press for Resources for the Future, Inc., 1965, 2nd printing,1972. 
argue that the coastal State effectively has property rights (the term in the convention is "sovereign rights") as a result of the following provisions:

"Article 61(1). It is the coastal State that establishes the TAC within the EEZ.
Article 62(2). The coastal State also decides its own capability to harvest the TAC
and whether or not there is any surplus to be shared.

Article 297(3). These decisions are at the heart of 'the discretionary authority of the coastal State' which may not be called into question via the dispute resolution mechanism (itself limited to conciliation only). As such, these decisions are nonreviewable by any third party."

It is true that the coastal State is obligated to avoid endangering stocks within the EEZ by over-exploitation but the only redress available to a plaintiff lies in convening a conciliation commission operating under the constraints noted above.

We should note, however, that even though coastal States are currently leading the fight against distant-water fishing nations (DWFNs), particularly with issues left somewhat murky in the 1982 Convention concerning straddling stocks and highly migratory species, most coastal States in the world do not come to the table with clean hands. The fact is that most coastal States are derelict in their responsibilities for managing fisheries within EEZs. They have chosen to put most of the restrictions on foreign fleets, i.e. the DWFNs, while they perpetuate the conditions of open access domestically. ${ }^{4}$ The consequences are that the world ocean is in worse shape now as far as the status of stocks is concerned, than it was prior to the emergence of extended coastal State jurisdiction and the level of over-capitalization in fishing fleets has vastly increased.

The issue of the effective management of high seas fisheries is not only a very difficult issue to tackle but is also a very sensitive one which is directly related to the stability of the new ocean regime created by the 1982 Convention. The Convention contains a delicate balance between the interests of coastal States and the interests of the international community. Where there is ambiguity in the provisions, as is the case with the provisions on straddling stocks (Article 63) and highly migratory species (Article 64), we must be careful that new policy, especially as it relates to the regime of the high seas, be clearly in the spirit of the Convention, with safeguards to protect community interest. If this delicate balance is tipped by policy innovations which have not been

4 See EDWARD Miles (ed), Management of World Fisheries: Implications of Extended Coastal State Jurisdiction, Seattle and London, University of Washington Press, 1989, esp. pp. 282-308. See also: Dept. of fisheries, FAO, with the assistance of FrANCIS T. CHRISTY, Jr., "Marine Fisheries and the Law of the Sea: A Decade of Change", in The State of World Food and Agriculture, Rome, FAO, 1992, FAO Fisheries Circular No. 853. FIDI/C853, 66 pp. 
adequately thought through, we run the risk of feeding the fires of further unilateral extensions of coastal State jurisdiction beyond 200 miles. This outcome will be neither equitable nor wise.

As a contribution to the on-going debate, this paper considers

(a) the nature of the high seas fisheries regime and present trends in high seas fisheries;

(b) continuing problems and deficiencies in the management of high seas fisheries; and

(c) the requisites for more effective management of high seas fisheries.

\section{THE NATURE OF THE HIGH SEAS FISHERIES REGIME AND PRESENT TRENDS IN HIGH SEAS FISHERIES}

\subsection{The Regime}

There are major differences in the geographic scope of the high seas between the current regime and the Grotian regime which preceded it but there are not major differences in the content of the rules which apply. As BURKE ${ }^{5}$ has pointed out, in the Grotian regime, the high seas included all but a narrow strip of the coastal ocean defined as the territorial sea, so almost all significant commercial fishing effort occurred in the high seas. Regulation of fishing operations occurred only pursuant to agreement negotiated among the States concerned. On the other hand, in the regime of extended coastal State jurisdiction, the high seas have been reduced to an area beyond the EEZ and most commercial fisheries are now contained wholly within 200 miles, subject to the unilateral control of the coastal State. However, the new regime has created many more shared stock management problems than existed previously and issues of straddling stocks and highly migratory species remain, along with the issue of effective management of purely oceanic stocks.

With respect to the content of the rules, the 1958 Convention on the High Seas ${ }^{6}$ confirms (Article 2) that freedom of fishing is a basic freedom of the high seas. This freedom is re-confirmed in the 1982 Convention (Article 87). Article 1 of the Convention on Fishing and Conservation of the Living Resources of the High Seas ${ }^{7}$ makes two important points:

5 William T. BuRke, "High Seas Fisheries", in press (1993) in: Jon VAN Dyke, Durwood ZaelKe, and Grant Hewison (eds.) Freedom for the Seas in the Twentieth Century: Ocean Governance and Environmental Harmony, Washington, D.C., Island Press.

6 UN Doc. A/CONF. 13/L.53, adopted 29 April 1958.

7 UN Doc. A/CONF. 13/L.54, adopted 28 April 1958. 
(1) All States have the right for their nationals to engage in fishing on the high seas, subject

(a) to their treaty obligations,

(b) to the interests and rights of coastal States as provided for in this Convention,

(c) to the provisions contained in the following articles concerning conservation of the living resources of the high seas.

(2) All States have the duty to adopt, or to cooperate with other States in adopting such measures for their respective nationals as may be necessary for the conservation of the living resources of the high seas.

The 1982 Convention repeats these two basic points but splits them into two separate articles (Articles 116-117). In addition, the reference to the "...rights and duties as well as the interests of coastal States..." is made more specific, i.e. "...provided for, inter alia, in Article 63, para. 2, and Articles 64-67..." Article 63, para. 2 refers to straddling stocks and Articles 64-67 refer to highly migratory species, marine mammals, anadromous species, and catadromous species.

The obligations which devolve upon high seas fishing States in the 1982 Convention (Articles 117-119) include the following:

(1) To conserve the living resources of the high seas (including the obligation to take unilateral measures for its own nationals when a fishery is conducted by them alone);

(2) to employ the best scientific evidence available to establish needed conservation measures;

(3) to cooperate with other States in conserving high seas living resources;

(4) to negotiate with other States over conservation measures;

(5) to generate, contribute, and exchange scientific and other information (e.g., catch and effort statistics); and

(6) to refrain from discrimination in the enactment of conservation measures.

\subsection{Present Trends in High Seas Fisheries}

In their comprehensive paper on high seas resources, GARCIA and MAJOWSKI ${ }^{8}$ distinguish three types:

(1) Neritic high seas resources or those associated in their life cycle primarily with the continental shelf or upper slope. In this case, these stocks either move in or out of EEZs or are associated with a continental margin

8 Serge Garcia and J. Majowski, "State of High Seas Resources". in Tadao Kuribayashi and EDWARD L. MiLes (eds.) The Law of the Sea in the 1990s, A Framework for Further International Cooperation: Honolulu, Law of the Sea Institute 1992, pp. 175-237, esp. pp. 175-176. 
which extends beyond 200 miles, as in the case of the Grand Banks off Nova Scotia and Newfoundland, Canada. Neritic high seas stocks can also exist where no EEZs have been declared, e.g. off China or in the Mediterranean.

(2) Stocks which have primarily oceanic life cycles beyond 200 miles. These are mainly pelagic stocks but they include mid-ocean demersal species which congregate over seamounts. In all there are about 400 species in this category, including 50 cephalopods, 40 sharks, 60 marine mammals, and 230 fish.

(3) All living resources of the Southern Ocean south of the Antarctic convergence. The Antarctic is a special case since the existing regime excludes State sovereignty over islands, continent, or ocean.

Note that the cost of fishing high seas resources is always greater than fishing within EEZs. This is so as a function of both distance (i.e., steaming time to fishing grounds, fuel consumption, labour, etc.) and density. The average densities of oceanic species are much lower than those found within EEZs as a function of greater depth, the absence of upwelling, and therefore the lack of nutrients in the photic zone.

Two conditions currently characterize high seas fishing operations. The species noted above congregate in hydrographic structures which accumulate plankton, mesopelagic species (i.e., those which occur at between $200 \mathrm{~m}-1000 \mathrm{~m}$ depth), krill, and various small prey fish. These aggregations naturally attract predators, like jacks, gadiod (codlike) species, squids, tunas, sharks, marine mammals, and humans. As EEZs enclose the most productive regions of the world ocean, DWFNs are pushed further out. These fleets search for and target such concentrations. However, given the lack of effective controls over fishing effort, these resources are usually overfished in the short run and the fleets move on to other concentrations.

Large-scale distant-water commercial fishing has existed only since World War II. The phenomenon is based on a combination of monofilament nets, atsea freezing and processing of the catch, in addition to significant technological innovations in fishing vessel design and capacity across all gear types, i.e. longline, trawl, purse-seine, driftnet, and pots. The development of modern, distant-waters fleets began first in Western Europe and Japan in the early to mid-1950s, followed by the USSR and the Eastern Europeans (Bulgaria, the DDR, and eventually Cuba). After these countries, Korea and Taiwan emerged, followed by Spain, Mexico, Venezuela and others focused primarily on purse-seining for tuna. One difficult control problem which has emerged has been the creation of "flag of convenience" fishing fleets under the registration of the Cayman Islands, Bermuda, and Vanuatu, among others. Once these open registries emerged, a considerable amount of re-flagging of fishing vessels has occurred, the purpose of which is to escape restrictive coastal State regulation. 
The recent FAO study cited above ${ }^{9}$ has made a major contribution to the current debate by showing that even after the introduction of EEZs, a lot of investment is still flowing into distant-water fleets. The reasons for this surprising development would include: the continued existence of open-access regimes, both on the high seas and within EEZs; the widespread practice of national subsidies for fishing fleets; and rising real prices for fish and fish products. On a global basis, the fishing industry is highly concentrated and overcapitalized. The FAO study has conservatively estimated that in 1989 the annual operating costs of the world marine fisheries fleet was about US\$15 billion greater than annual revenues and capital costs were not included in this estimate.

There is also cause for concern when one looks at current trends in world catch. ALVERSON and LARKIN, ${ }^{10}$ using data published by FAO, note that the total world catch in 1990 (marine and fresh water) amounted to more than 100 $\mathrm{mmt}$. or a $33 \mathrm{mmt}$. increase since the 1970s. However, only 20 species contribute most of the world marine catch. Of these 20 , seven are highly volatile coastal pelagics (herrings, sardines, anchovies, etc.). These yields are not stable: the Japanese sardine catch for example, went from 9,000 mt. in the mid-1950s to $5.1 \mathrm{mmt}$. in 1989. Like the Peruvian Anchovetta, this production will decline precipitously in the future and there will be a lag before another species moves into the niche vacated by the Japanese sardine. Similarly, since 1970, there has been a $1.5 \mathrm{mmt}$. increase in the whitefish category (cods, hakes, red fishes, flounders, etc.), but this increase is based on a single population of North Pacific pollock.

In addition to unstable increases in coastal pelagics and the major increases in North Pacific pollock production, more stable increases have occurred in two areas; in the production of skipjack and yellowfin tuna in the West Central and Southwest Pacific and in the production of shrimp from aquaculture where world production, now in excess of $2 \mathrm{mmt}$., has more than doubled since 1970.

Looking at the same data considered in the 1992 FAO study cited above, ALVERSON and LARKIN infer that the increasing conflicts over access to world fish resources which we are all now experiencing is driven by increasing demand for fish and fish products and the imbalance which exists between aggregate fleet capacity and available resources. This demand is, of course, driven by world population. Using the UN projection that by 2025 the world population will be at 8 billion, ALVERSON and LARKIN note that fish and fish products currently provide about 50 per cent of total animal protein consumed,

9 "Marine Fisheries and the Law of the Sea: A Decade of Change," FAO Fisheries Circular No. 853, 1992.

10 Dayton L. Alverson and Peter A. Larkin, "Fisheries: Fisheries Science and Management", in Century 21, Proceedings of the World Fisheries Conference held in Greece in 1992, in press, American Fisheries Society, 1993. 
either directly, or indirectly as fishmeal for poultry or livestock. If the same proportion is to exist in 2025, total world catch must increase 1.6 times the present catch to about $160 \mathrm{mmt}$.

Such a large increase is very unlikely. What is far more likely is a decline in world catch as a result of the natural variability in the yield of coastal pelagics. The shortfall in production relative to steeply growing demand will provide a major additional boost for aquaculture, where Asia is by far already the dominant producer. Such a growing imbalance between demand and supply will further accentuate conflicts over access to fisheries resources.

Let us now return to my charge, stated at the beginning of this paper, that even though coastal States are now leading the attack on DWFNs, the former do not come to the table with clean hands. ALVERSON and LARKIN point out that, of the 176 stocks of stock complexes for which we have data in the FAO Yearbook of Fishery Statistics for 1990, seven were under-exploited, 39 lightly to moderately exploited, 79 fully to intensely exploited, and 51 ( 29 per cent) were over-exploited. It is this trend that is most disturbing since, in 1983, 20 stocks were unexploited, as opposed to seven in 1990 and 23 were overexploited as opposed to 51 in 1990.

All of this has occurred after the introduction of EEZs. Not every failure is a failure of management, to be sure, because the ocean environment itself is a powerful generator of inter-annual variability in fish stocks. But a lot of the failures are management failures and most coastal States as well as DWFNs have simply failed to enact comprehensive effort controls. Moreover, many of the failures have occurred within EEZs, not only on the high seas. For instance, 38 stocks (or 53 per cent) of a total of 72 stocks in the Northwest, Northeast, East Central, and Southeast Atlantic have been overfished to a considerable degree. DWFNs bear most of the responsibility in the East Central and Southeast Atlantic but they are not responsible for the failures which have occurred in the Northeast Atlantic. And it must be admitted that a considerable amount of overfishing in the Northwest Atlantic has been done by US and Canadian fishermen.

\section{CONTINUING PROBLEMS AND DEFICIENCIES IN THE MANAGEMENT OF HIGH SEAS FISHERIES}

The current focus on high seas fisheries is inextricably linked to developments within EEZs. First, DWFNs have been displaced from many traditional fishing grounds now coming within coastal State jurisdiction. Consequently, they seek new areas to fish free of such constraints. At the same time we have seen the rapid expansion of coastal State fleets, of which the US 
West Coast is a prime example. ${ }^{11}$ As fishing effort increases, allocation conflicts intensify between coastal State fleets and the DWFNs. These allocation conflicts are far more complex than the traditional conflicts over fishing grounds. They now embrace national, and in the case of the EEC, even regional strategies with respect to a wide range of harvest and marketing opportunities.

As conflicts over fisheries fester, they become entangled with conflicts between environmentalist organizations in the US, Canada, Western Europe, and Australia, and certain DWFNs over driftnets, marine mammals, and increasingly the use of purse-seines to catch tunas in the Eastern Tropical Pacific. Strange alliances are then formed between certain groups of fishermen, especially in North America, and environmentalist organizations against DWFNs. But what this process often masks is that, the question of values apart, much of the root of current problems is in fact overcapitalization, both old and new, in fishing fleets.

Having recognized that coastal States themselves are as much to blame as DWFNs, we must also recognize that we face here a genuine dilemma which is not susceptible to easy resolution. The fact is that the traditional regime for the management of high seas fisheries is demonstrably ineffective because it is based on the principle of flag State control. On the other hand, if coastal States are permitted to extended jurisdiction beyond 200 miles, the consequences will assuredly be the disintegration of the current regime for the world ocean and an increase in national control. But, as we have already seen, such an eventuality will not solve the problem either. It will only result in greater restrictions on "foreigners" at the same time that the coastal State itself feeds the fires of overcapitalization.

How do we get out of this dilemma without incurring the disintegration of the present regime? Let us focus on the entire set of problems which are now on the table, i.e., not only straddling stocks and highly migratory species but the large question of how to increase the effectiveness of high seas fisheries management generally. Before we offer prescriptions for solving these problems, let us be clear about the deficiencies of high seas management regimes. We would argue that there are four major ones:

(1) Participation in the regime and in its management organizations often does not include all participants in a fishery. This gap leads to the

11 See: E.L. MiLes, "The Evolution of Fisheries Policy and Regional Commissions in the North Pacific Under the Impact of Extended Coastal State Jurisdiction", in Essays in Memory of Jean Carroz: The Law and the Sea, FAO, Rome, 1987, pp. 139-157; DANIEL D. HUPPERT, Managing Alaska Groundfish: Current Problems and Management Alternatives, Seattle: Fisheries Management Foundation and the Fisheries Research Institute, April 1988, FMF, FRI-001, 83 pp.; and EDWARD L. Miles. The US/Japan Fisheries Relationship in the Northeast Pacific: From Conflict to Cooperation? Seattle, Fisheries Management Foundation and the Fisheries Research Institute, July 1989 FMF-FRI-002, 128 pp. 
problem of new entrants, of which the re-flagging issue is but a subset. The problem of new entrants is, in fact, one of the most difficult issues to be solved in international fisheries management. On the one hand, parties to any arrangement could claim that once the TAC is fully allocated, no new entrants could be permitted without endangering the stocks in question and therefore violating the duty to conserve. New entrants, however, always have the right to claim access on the basis of the freedom to fish high seas resources and therefore to demand a share within the agreed TAC. Since exclusion of new entrants is currently beyond what international law permits, most regional arrangements simply reduce the magnitude of the share available to each party in order to accommodate new entrants. Even if they did not do so, the inability to enforce on the high seas against vessels flying the flags of non-parties to the arrangement would yield the same effect.

(2) High seas management organizations often lack the requisite authority:

(a) independently to assess the status of stocks and determine TACs, especially biomass and species quotas;

(b) to decide on the basis of majority vote; and

(c) to enforce management decisions.

(3) All high seas fisheries management regimes leave as matters to be negotiated the components that really count in fisheries management, i.e., effort controls, data gathering and quality controls, and penalties.

(4) Most high seas management organizations lack the financial resources to perform their tasks effectively.

The current debate so far has not focused on these basic flaws in the system. Instead, it has taken on a strong coastal State versus DWFN cast which is unlikely to produce fundamental solutions. As we have stated above, the current debate has so far only revolved around two issues.

With respect to highly migratory species, the problem arises only with respect to high seas enclaves surrounded by EEZs. This issue is therefore most acute in the West Central and South Pacific region. In that context, coastal States argue that within the terms of Articles 61 and 62 of the 1982 Convention, they can make access to their EEZs by DWFNs in part contingent on certain behaviour within these high seas enclaves, especially with respect to providing data and information on catch and effort. Such a provision is of course enshrined within the regional treaty between the South Pacific and the US. More problematic, however, have been the bilateral negotiations between particular island States and the governments and/or fleets of Japan, Korea, and Taiwan.

The issue of principle raised by the DWFNs is that they are not obligated under international law to provide data and information to coastal States concerning fishing operations conducted on the high seas adjacent to EEZs. The response of the South Pacific Forum Fisheries Agency (FFA) has been for member States to enact within their respective national legislations certain 
minimum terms and conditions pertaining to access for DWFNs within EEZs. As such, these provisions become non-negotiable and there is grudging acceptance of the rule by DWFNs at least vis- $\dot{a}$-vis those island States with traditionally the most productive zones. Japan, however, remains adamant on the issue of principle, even though the trend in State practice is toward the position favoured by island States.

In particular, the Japanese maintain that it is impractical and unfair for FFA and its member States to attempt to manage tuna fisheries within EEZs and in the high seas enclaves by an organization that includes as members only coastal States. Such a grouping, they argue, cannot provide adequate scientific assessment of tuna resources throughout their range of migration.

With respect to the issue of straddling stocks, on the one hand, coastal States and some commentators ${ }^{12}$ argue that coastal States have a superior right under the 1982 Convention with respect to straddling stocks. On the other hand, DWFNs reject the notion that coastal States have superior rights over straddling stocks and they maintain that coastal States and DWFNs in this context stand on equal footing. ${ }^{13}$ The result of this disagreement on principle is that very often in negotiation over the management of straddling stocks, parties arrive at an impasse over two issues: allocations and enforcement. An additional problem of importance, even if agreement is reached, is again the issue of new entrants.

\section{THE REQUISITES OF MORE EFFECTIVE MANAGEMENT OF HIGH SEAS FISHERIES}

The most important event which must occur in order to begin moving towards more effective high seas fisheries management would be a general recognition among the international community that there is an urgent need to break away from the common property/open access regimes of the past and present. It seems that there is very little support for the idea of vesting property rights to high seas living resources in a global organization. If this avenue is closed, then the only apparent alternative available is to seek to strengthen the duty to cooperate and the duty to conserve by means of agreement on a set of

12 See, for instance, Edward L. Miles and William T. BurKe, "Pressures on the Convention on the Law of the Sea of 1982 Arising From the New Fisheries Conflicts: The Problem of Straddling Stocks", Ocean Development and International Law Journal, Vol. 20 (1989) pp. 343-357.

13 See Kunio Yonezawa, "Some Thoughts on the Straddling Stock Problem in the Pacific Ocean", in Tadao Kuribayashi and Edward Miles (eds), The Law of the Sea in the 1990s: A Framework for Further International Cooperation, Hawaii, Law of the Sea Institute, 1992 pp. 127135. See also the paper submitted to the FAO Technical Consultation on High Seas Fisheries, 7-15 September 1992 by the Government of Japan: "Basic Position of Japan at the FAO Technical Consultation on High Seas Fishing". 
principles to guide high seas fisheries management and by attempting to shape the development of customary international law beyond, but in the spirit of, the 1982 Convention.

Lest it be thought that we have too hastily dismissed the possibility of agreement on vesting property rights in a global organization, let us recall ${ }^{14}$ that the provisions that exist in the UN Convention of 1982 relating to high seas fisheries are

(1) those that emerged in the ISNT in 1975 and remained unchanged until 1982;

(2) that the basic framework for these provisions was derived from the 1958 Conventions on the High Seas and on Fishing and the Conservation of the Living Resources of the High Seas; and

(3) that early in the negotiations "...there were suggestions that high seas fisheries should be managed internationally..." by the International Seabed Authority, inter alios. ${ }^{15}$

These proposals never garnered enough support to warrant inclusion in the Convention.

Another alternative approach that some might find appealing is to pursue an extreme application of the precautionary principle combined with coercive diplomacy and the threat of trade sanctions after the example of General Assembly Resolutions 44/225 (1989) and 46/215 (1991) and the policy of the US government with respect to the use of high seas pelagic driftnets. In our view, this would be a severe mistake since there is no evidence to support a complete global termination of pelagic driftnetting on the high seas and what evidence is available does not indicate that any marine exosystem is in danger of imminent collapse. ${ }^{16}$ The precautionary principle is not an instrument that should routinely be resorted to because it is very blunt and categorical. It is most appropriately a response to a crisis situation. Its justification must rest on the basis of some evidence that collapse is imminent.

On the basis of the argument elaborated above, we see no feasible alternative to the suggestion we have made earlier, i.e. seek to strengthen the duty to

14 United Nations, Office for Ocean Affairs and the Law of the Sea, The Regime for High Seas Fisheries: Status and Prospects, 24 September 1991, pp. 10-11.

15 See J.E. CARroz, "Institutional Aspects of Fishery Management Under the New Regime of the Oceans," San Diego Law Review, Vol. 21 (1984), pp. 516-517.

16 This case has been elaborated both separately and jointly by WILLIAM BURKE, MARK FreEberg, and EDWARd Miles. See Robert W. SchonIng et al (eds.), Proceedings of the National Industry Bycatch Workshop, 4-6 February 1992, Newport, Oregon: MARK W. FreEBERG, "A National and International Perspective on Bycatch and Bycatch Management", pp. 15-22, esp. pp. 18-19; Dr. William T. BURKe, "An International Legal Perspective on Bycatch", pp. 23-29; Dr. EDWARD L. MiLes, "The Need to Identify and Clarify National Goals and Management Issues Concerning Bycatch", pp. 169-177, esp. pp. 171 and 174. See also: William BurKe, MARK FreEberg, and EDWARD MILES, The United Nations Resolution on Driftnet Fishing: An Unsustainable Precedent for High Seas Fisheries Management (in press, July, 1993). 
cooperate and to conserve through a set of principles and attempt to shape the development of customary international law. These principles must safeguard living resources while at the same time protecting the community interest in free navigation on the high seas. They must also carefully balance biological and economic approaches to management by means of comprehensive controls on fishing effort, quotas, closed areas and seasons, mesh size regulations, and bycatch regulations.

For such an effort to succeed, we cannot stop at principles alone but must move on to implementing effective monitoring and enforcement approaches; systems for gathering and exchanging scientific data, information, and analysis; pre-agreed allocation mechanisms, including the issue of how to deal with new entrants; and, finally, effective dispute settlement mechanisms.

How shall these major and difficult objectives be secured? The FAO (1992) study suggests a basic principle and a set of strategies which are highly informative and which should be carefully considered. ${ }^{17}$ This policy is applicable equally within as well as beyond EEZs. The principle is that the international community should treat fishery resources as resources which have value in situ. This value is definable in monetary terms. Accordingly, the community should seek stability by sharing the benefits generated by the use of these resources. Benefits should be used to provide compensation for the less well-endowed members of the regime.

The strategies which are recommended proceed in step-wise progression:

Step 1 The community should seek to move from management based on physical quantities (i.e., amount of catch) to management based on economic values. From this perspective, the community should seek to maximize not physical quantities (catch) but net economic revenues from the exploitation of living resources. One can achieve this objective through implementation of vessel licences, transferable use rights, and transferable individual shares of the TAC, or total revenues, or total allowable investment.

Step II The community should then create the means for extracting the economic rents from the exploitation of high seas living resources. Such extraction can be achieved by auctioning use rights and imposing taxes or user fees for all stocks which are fished, including straddling stocks. However, if the latter are being dealt with, one must calculate stock value in terms of maximum economic rents from the entire stock, both within and outside EEZs. In this connection, preferences can of course be given to coastal States but, if such preferences are awarded, they should be in the form of distribution of revenues rather than lower access

17 See: "Marine Fisheries and the Law of the Sea: A Decade of Change", FAO Fisheries Circular No. 853, pp. 41-42. 
fees. Lower access fees should be avoided because they only serve to attract fishing effort and thereby dissipate potential economic rent.

Step III The community should establish a system for distributing the benefits generated. These benefits are defined as total economic rents minus the costs of administration, research, and enforcement. The distribution of benefits must be managed to assure stability of the regime. All parties to the arrangement must feel that they are better off from collaboration than they would be from unilateral action, although the amounts of individual shares would be subject to negotiation.

One does not need a centralized global organization to manage high seas fisheries in order to achieve the objectives outlined above. One needs a change in the emphasis of the applicable international law and a change in perceptions. The change in emphasis requires less stress on the freedom of all States to fish the high seas and far more stress on the duty to conserve. Consequently, this shift in emphasis will imply that new entrants do not have the right to enter into a fishery in which the TAC is fully allocated and in which benefits are being shared. The shift in perceptions relates to the way in which we manage fisheries. At the national level, the Government of New Zealand has shown that one can move from a chaotic, ineffective system if one has control over the stocks and if one has the will to insist on creating a system that deliberately seeks to maximize the economic returns to society of exploiting living resources. ${ }^{18}$

At the global level, no one per se has control over the stocks but we can choose to treat control as being vested in the international community and change the rules to strengthen the duty to conserve. We can also choose to experiment with the basic principle and strategies suggested by FAO. The first step is to move away from the perception that we must always seek to maximize amount of catch and instead to embrace the notion that we should maximize economic values. This shift is a question of political will at the level of the global community. Failure to make this choice soon will imperil not only the resources but also the stability of the current regime governing human activities on the world ocean. Regime instability and breakdown will lead only

18 See, inter alia: IAN N. CLARK and PhILIP J. MAJOR, "Development and Implementation of New Zealand's ITQ Management System", Marine Resource Economics, Vol. 5 (1988), pp. 325-349; IAN N. Clark and AleXander Duncan, "New Zealand's Fisheries Management Policies-Past, Present, and Future: The Implementation of an ITQ-Based Management System" in NINA Mollett (ed.), Fishery Access Control Programs Worldwide, Proceedings of the Workshop on Management Options for the North Pacific Longline Fishery, Alaska Sea Grant Report No. 86-4; and Peter H. Pearse, "From Open Access to Private Property: Recent Innovations in Fishing Rights as Instruments of Fisheries Policy", in Alastair Couper and EDgar Gold (eds), The Marine Environment and Sustainable Development: Law, Policy, and Science, Honolulu, Law of the Sea Institute,1993, pp. 178-195. 
to further unilateral extensions of coastal State jurisdiction.

Specifically, what principles should we seek to embrace in an attempt to strengthen the duty to conserve? The seven principles that are offered below are based on some of the recommendations of the International Conference on the Conservation and Management of the Living Resources of the High Seas, sponsored by the Government of Canada in St. Johns, Newfoundland, 5-7 September 1990. However, principle 7 is not derived from that Conference. A variety of guidelines has also been offered by the UN Office of Ocean Affairs. ${ }^{19}$ These guidelines are more extensive than, but not incompatible with, the principles offered below.

Fisheries conducted on the high seas must be consistent with the following principles and/or conditions:

(1) Adequate and verifiable statistics must be provided on the catch and effort utilized to harvest target and non-target fish, marine mammals, birds, and/or other sea life.

(2) The fishery must be conducted in a manner so that it does not jeopardize the option of achieving the maximum sustainable yield of the target species.

(3) The fishery should not result in a substantial reduction or depletion of non-target species (bycatch).

(4) The fishery should not be directed toward species fully utilized by fisheries conducted from the adjacent coastal States.

(5) The fishery activity should be compatible with and not detrimental to the environment.

(6) Fisheries regulations applicable on the high seas should be compatible with regulations applicable in EEZs.

(7) The obligation to conserve high seas resources includes the possibility of closing a fishery to new entrants once the optimum yield is fully allocated. Closing fisheries on the high seas to new entrants raises questions of equity and enforceability. Equity can be dealt with through approaches to taxation. Enforceability requires some additional controls on flag State jurisdiction tied to a dispute settlement procedure.

It is worth noting that principle 6 puts the onus on coastal States to improve their management performance as much as it does for DWFNs on the high seas. The principle recognizes that where coastal States have been diligent in implementing their management responsibilities, the benefits of such actions should not be dissipated by lax behaviour of DWFNs fishing the high seas adjacent to the EEZs in question. But, equally, the principle implies that coastal States cannot reasonably expect to be lax in their EEZs and to put the burden of effective management solely on DWFNs operating beyond EEZs.

Principle 7 is novel and controversial but it shows the direction in which we

19 The Regime for the High Seas: Status and Prospects, 1991, pp. 38-40. 
think the international community should seek to shape the development of customary international law. It is controversial because it reduces, to some extent, the scope of jurisdiction of the flag State, subject to certain powerful constraints. But the idea is not new, really. It is derived from the 1958 Convention on Fishing and Conservation of the Living Resources of the High Seas and was used by WILLIAM BURKE and EDWARD MILES to shape their recommendations for solving problems concerning straddling stocks. ${ }^{20}$ Because solving the new entrants problem is so fundamental to achieving effective management of high seas resources, the same idea can be generalized for this purpose.

The 1958 Convention on Fishing notes (Article 6) that the coastal State has a special interest in the conservation of living resources in any area of the high seas adjacent to its territorial sea. Article 116 of the 1982 Convention extends this interest beyond the territorial sea to the EEZ and adjacent high seas. The 1958 Convention also permitted unilaterally prescribed regulations by any coastal State party for adjacent high seas fisheries in default of agreement, subject to binding dispute settlement on the basis of agreed scientific standards.

In order for such action to be valid, it must meet certain tests as specified in Article 7 of the 1958 Convention of Fishing:

(a) That there is a need for urgent application of conservation measures in the light of the existing knowledge of the fishery;

(b) That the measures adopted are based on appropriate scientific findings; [and]

(c) That such measures do not discriminate in form or in fact against foreign fishermen.

As it stands, both conventional and customary international law require States fishing the high seas to cooperate to conserve the living resources subject to exploitation by their nationals to negotiate to this end, and to regulate their nationals as necessary. It is but a small step, therefore, to require that where more than one State is engaged in fishing high seas resources, such exploitation be conducted only pursuant to international agreement among the parties concerned. The machinery for insuring effective management is already embedded in conventional and customary international law and this machinery increasingly contains joint inspection or surveillance enforcement schemes. The proposal for strengthening the duty to conserve therefore generalizes the procedure envisaged in Article 7 of the 1958 Convention to all parties to the particular international agreement, not just the coastal State.

By making the right to fish subject to international agreement, the means exists for controlling the problem of new entrants via the management infrastructure and the joint surveillance and enforcement scheme. Yet, the parties to the agreement are themselves subject to the constraints set out in

20 Miles and BURKE, loc.cit. n. 12, esp. pp. 350-356. 
Article 7 of the 1958 Convention on Fishing. There remains only the necessity of tying these recommended changes in the law to an explicit and binding dispute settlement procedure, such as that recommended in Article 9 of the 1958 Convention. 